\title{
The Status of Social Responsibility and its Dimensions in Public Hospitals of Mashhad: A Cross-Sectional Study
}

\author{
Hossein Ebrahimipour $^{1}($ D $)$, Fatemeh Fathi ${ }^{2 *}$ (D), Elahe Houshmand ${ }^{3}$ (D), Ali Taghipour ${ }^{4}$ (D), Seyed Javad \\ Hoseini $^{5}$ (D)
}

\begin{abstract}
Introduction: Social responsibility is a concept in which organizations pay particular attention to environmental and social issues in its business processes. The purpose of this study was to investigate social responsibility dimensions in public hospitals affiliated to Mashhad University of Medical Sciences in 2019.

Methods: In this cross-sectional and analytical study, social responsibility and its dimensions in 13 public university hospitals of Mashhad were examined using a questionnaire based on 273 samples of staff and customers. Data were analyzed using descriptive statistics (frequency, mean, and standard deviation) using SPSS software version 11.

Results: The highest mean score (2.40) was related to leadership and internal processes, and the lowest mean score (1.83) was related to workplace dimension. The other average scores from highest to lowest were: environmental dimension (2.08), market dimension (2.01), and community and country dimension (1.92). Overall, the social responsibility of the hospitals under study was significantly different from the mean level of $2(2 / 05)$, and considering the positive t-statistic for comparing a sample, it can be concluded that social responsibility was significantly higher than the average level $(p$-value $\leq 0.05)$

Conclusion: Improving the employment status of employees as the most important social capital is very important, which had the lowest score in this study. According to the results of the research, the existence of discrimination and work shifts reduced the satisfaction in this dimension. Lack of employee awareness has been the most important reason for the decrease, which can be promoted by increasing the awareness of employees in this dimension.
\end{abstract}

Keywords: Social Responsibility, Hospitals, Iran.

$\bullet$ Received: 17/Dec/2019 •Modified: 29/Feb/2020 •Accepted: 16/March/2020

1. Professor, School of Health, Mashhad University of Medical Sciences, Mashhad, Iran, ebrahimipourh@mums.ac.ir.

2. MSc, Mashhad University of Medical Sciences, Mashhad, Iran; Corresponding Author, fathif3@mums.ac.ir.

3. Assistant Professor, School of Health, Mashhad University of Medical Sciences, Mashhad, Iran, houshmande@mums.ac.ir.

4. Associate Professor, Social Determinants of Health Research Center, Mashhad University of Medical

Sciences, Mashhad, Iran, taghipoura@mums.ac.ir.

5. Assistant Professor, School of medical, Mashhad University of Medical Sciences, Mashhad, Iran,

hoseinij@mums.ac.ir. 


\section{وضعيت مسئوليت اجتماعى و ابعاد آن در بيمارستانهاى دولتى شهر مشهرد: مطالعه مقطعى}

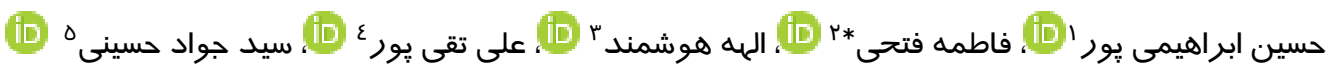

קكيده

مقدمه: مسئوليت اجتماعى به معناى توجه ويزه سازمانها در فرآيندهاى كسبوكار به مسائل زيستمحيطى و اجتماعى است. هدف مطالعه حاضر، تعيين ابعاد مسئوليت اجتماعى بيمارستانهاى دانشكاهى دولتى شهر مشهد در سال Ir IV است. روشها: مطالعه حاضر از نوع تحليلى و مقطعى بود. دادهایى مرتبط با مسئوليت اجتماعى و ابعاد آن ازنظر rV نفر از كاركنان و مراجعين در بيمارستانهاى دولتى دانشكاهى شهر مشهد با استفاده از يرسشنامه استاندارد بررسىشده و با استفاده از آمار توصيفى (فراوانى، ميانكين و انحراف معيار) و آزمون آمارى تى به كمك نرمافزار SPSS نسخه 11 در سطح معنىدارى • • • تحليل شد. يافته ها: بيشترين ميانكين امتياز ( •ع/Y) مربوط به بعد رهبرى و فرآيندهاى درونى و كمترين ميانكين امتياز (T/N/) مربوط به

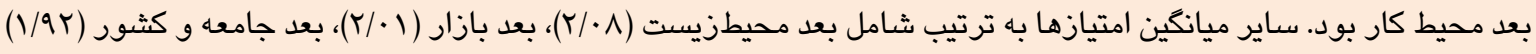
بوده است. درمجموع، مسئوليت اجتماعى بيمارستانها تفاوت معنىدارى با سطح متوسط يعنى دو دارد ( (Y/0) و با توجه به مثبت بودن آماره تى براى مقايسه يك نمونه مىتوان نتيجه كرفت كه مسئوليت اجتماعى بهطور معنادارى كمى بيشتر از سطح متوسط است. (Pvalue نتيجه ئرى: ارتقاء وضعيت كارى كاركنان به عنوان مهمترين سرمايه اجتماعى اهميت زيادى دارد كه در يذوهش حاضر كمترين امتياز را به خود اختصاص داده است. با توجه به نتايج بِّوهش، وجود تبعيض و نيز نوبتهاى كارى سبب كاهش رضايت در اين بعد شده است. عدم آكاهى كاركنان مهمترين دليل كاهش بوده است كه مىتوان با افزايش آكاهى كاركنان مسئوليت اجتماعى در اين بعد را ارتقاء بخشيد. وازههاى كليدى: مسئوليت اجتماعى، بيمارستان، ايران

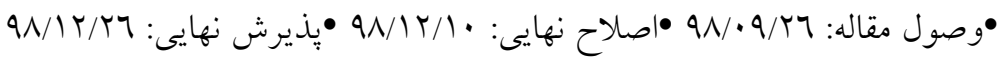

1. استاد، دانشكده بهداشت، دانشكاه علوم يز شكى مشهد، مشهد، ايران،

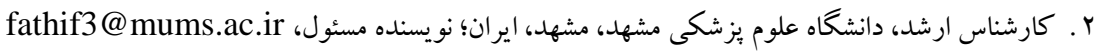

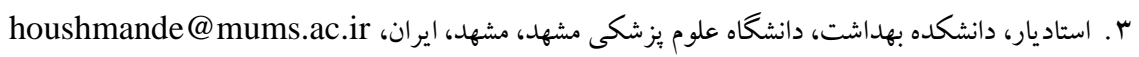

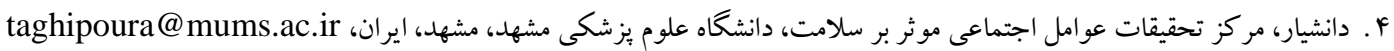

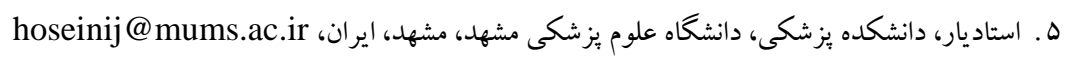


توجه به مسئوليت اجتماعى نه تنها از سوى سازمانها بلكه از سوى بيماران و جامعه هم از توجه برخوردار است. ون بين ليو در مطالعه خود در كشور خين نشان داد كه مسئوليت

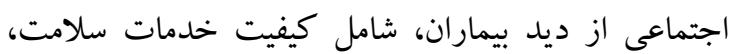
اخلاق حرفهاى و دسترسى به خدمات براى تمام بيماران

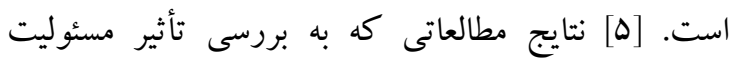
اجتماعى با بهرهورى، وفادارى مشتريان و تعهد كاركنان يرداختهاند شواهد قابل قبولى از ارتباط مستقيم و تأثير ونائ مسئوليت اجتماعى با موارد يادشده داشتهاند. [10] نتايج

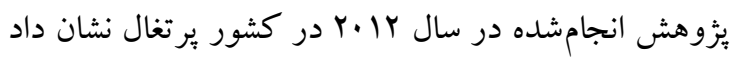
تعداد سازمانهايى كه به مسئوليت اجتماعى توجه نشان

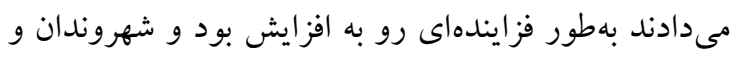

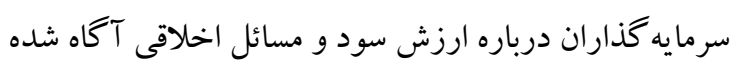

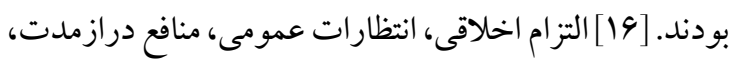
دلسردى از قوانين آينده دولت و منافع سهامداران منجر به نياز

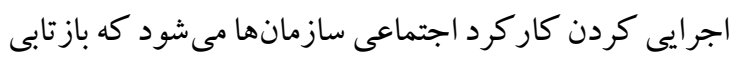
از اصلاحات كلان در بخش بهداشت و درمان است. [• إن مكس و كلاركسون در مطالعه خود در كانادا بيان داشتهاند كه هيج تعريف مشخصى از مسئوليت اجتماعى سازمان وجود ندارد تا يكك جارجوب يا مدل براى جمع آورى نظاممند را فراهم كند. [IV] دالسرود در مطالعه خود تعاريف مسئوليت اجتماعى يك يديده را توصيف

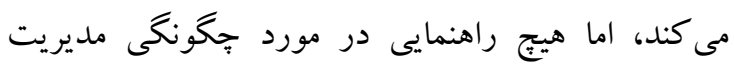
جالشها در اين مورد ارائه نمىدهند بنابراين بايد بدانيم

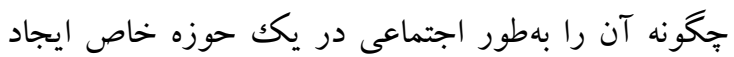
كرده و در استر اتزى كسبو كار در نظر بخيريم. [؟] در ايران مطالعه اعتمادى، نشان مىدهد عليرغم كاهش هزينهاى بيماران در طرح تحول سلامت، انخيزه بيمارستانها در مورد

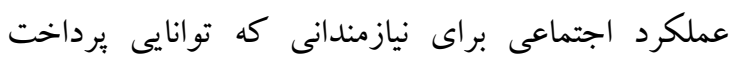

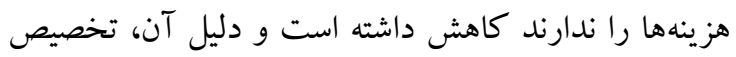

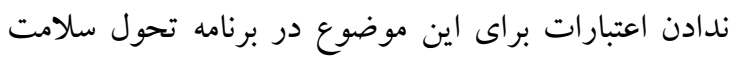

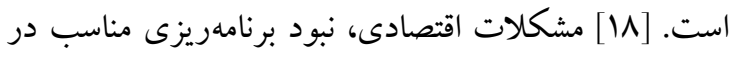
درازمدت، ضعف يا فقدان مسئوليت اجتماعى در كشور

\section{مقدمه}

كاركرد اجتماعى، شفافيت روشهاى مؤسسات در مديريت موضوعات محيطى، اقتصادى و اجتماعى است كه

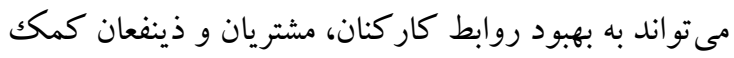
كند. [1] كار كرد اجتماعى، اصلى است كه سازمانها براى اثرات هر يكك از اقدامات خود در جامعه و محيطزيست بايد

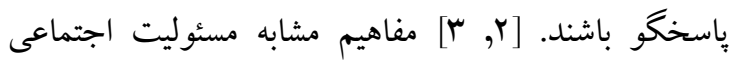

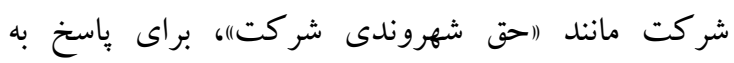

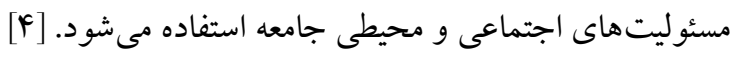
امروزه نقش بسيارى از بيمارستانها از ارائه خدمات سلامت حياتى به مديريت منابع كمياب با محدوديتهاى مالى تغيير ييداكرده است. [ه] اصول اخلاقى و رفتارهاى انسان دوستانه داراى اولويت بيشترى نسبت به كسب عملكرد اقتصادى برتر براى برخى از شر كتها است. ازاينرو بخشى از بودجه خود راصرف مسائل اجتماعى جامعه مى نمايند. [4]

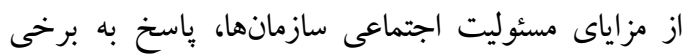
نيازهاى جامعه مبنى بر رعايت موازين اخلاقى است كه سبب

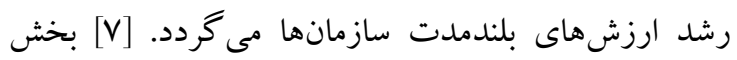
سلامت همانند ديخر سازمانهاى جامعه كه سعى دارند از راه تعامل تخصصها، خدمات بهداشتى و درمانى را به جامعه ارائه دهند، بايد يذيراى مسئوليت اجتماعى باشند. [^]

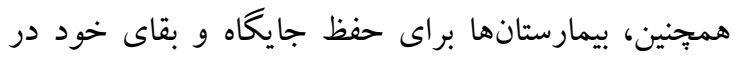
جامعه، مسئوليت اجتماعى را بايد در اولويت برنامههاى خود قرار دهند. [9] از عوامل مؤثر بر اجراى مسئوليت اجتماعى بيمارستانها به رسميت شناختن آن توسط دولتها و اختصاص منابع مالى بهصورت يارانه است. [• [1] همجنين، دئه

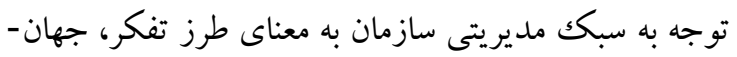

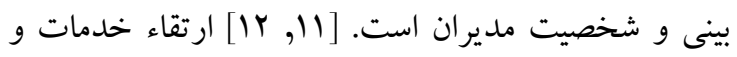

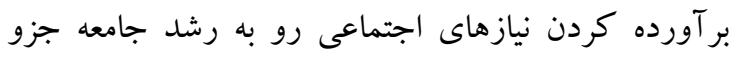

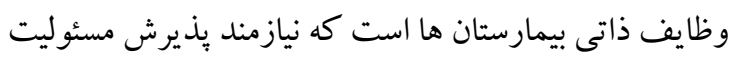

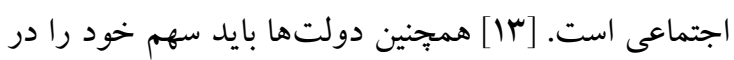
مسئوليت اجتماعى بيمارستانها ايفا نموده و با اختصاص منابع لمان مالى لازم آن را تسهيل نمايند. [IF] 
اطلاعات از ابزار برسشنامه استفاده شد كه با اين برسشنامه همراه با جمع آورى اطلاعات دمو گرافيك (سن، جنس و تحصيلات) با بو سؤال بسته ميزان مسئوليت اجتماعى (يرسش نامه سجادى) نيز را سنجيده شد. [II] الكوى ارزيابى مسئوليت اجتماعى در قالب ينج بعد تشكيل دهنده شامل مسئوليت اجتماعى سازمان در رهبرى و فر آيندهاى درونى، در بازار يا مشتريان، در محيط كار يا كار كنان، در محيطزيست و مسئوليت اجتماعى سازمان در جامعه و كشور تنظيم شد. جهت بررسى روايى صورى در جامعه مطالعه شده، ازنظر اساتيد و خبر گان استفادهشده است و يايايى با روش آلفاى كرونباخ در يكك نمونه اوليه به حجم

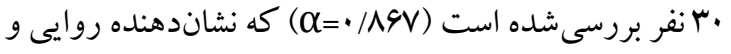
پايايى مناسب ابزار بزووهش است. نحوه ياسخدهى به سؤالات در هر يرسشنامه، با مقياس ليكرت و در سه طيف انتخاب (ضعيف)، (امتوسط))، (اخوب)) تنظيمشده بود كه درنهايت از يكك تا سه امتيازدهى شد. همجينين، ميانخين امتياز كمتر از دو و بالاتر از دو به ترتيب مسئوليت اجتماعى ضعيف و خوب ارزيابى گرديد. بر اساس مطالعه سجادى و همكاران [1/]، در ابعاد مختلف مسئوليت اجتماعى واريانس هاى متعددى ديده شده است و در اين بثزوهش حداكثر ميزان انحراف معيار براى ابعاد I/IV بهدست آمده است كه با احتساب خطاى هـ/ •، حجم نمونه برابر ·سا شده است كه با توجه به اينكه خطا كمتر از هـ/ •در هر يكك از گروهها (بيماران، كار كنان) مدنظر بود، از گروه بيماران ·سا نفر، گروه كار كنان ·سا نفر و تمامى سا نفر مدير كه درمجموع سلr نفر بررسى شدند و روش نمونه گيرى براى هر واحد بيمارستانى شامل يكك مدير بيمارستان، · ا بيمار و

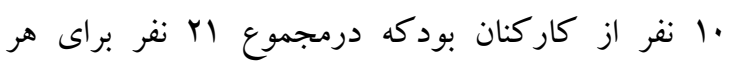
بيمارستان در نظر گرفته شد. سا بيمارستان دولتى شهر مشهد در يزٔوهش وارد شدند. با در نظر گرفتن هر بيمارستان بهعنوان يكك طبقه، جهت انتخاب نمونه تمامى مديران بيمارستانها و بهصورت تصادفى نظامند ·1 نفر از كاركنان و ·1 نفر از
وضعيت مسئوليت اجتماعى و ابعاد...

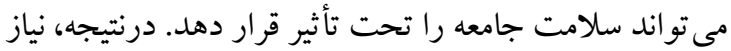
به راهاندازى سيستم پايش عدالت در سلامت است. [19] اجراى مسئوليت اجتماعى بايد ابعاد آن را مدنظر قرارداد، عرب صالحى در مقالهاى ابعاد مسئوليت اجتماعى را در جهار بعد مشتريان، كاركنان، محيطزيست و نهادهاى موجود در جامعه بررسى كردهاند. [•r] كارول تعريفى جهاربخشى از مسئوليت اجتماعى تحت عنوان اقتصادى، قانونى، اخلاقى و اختيارى ارائه نمود. [ (IY] در كتاب) ابزار سنجش و رتبهبندى مسئوليت يذيرى و ياسخكويى اجتماعى

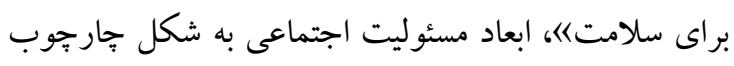

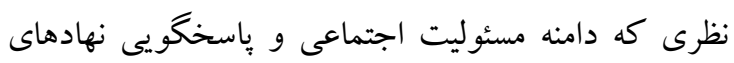
اجتماعى و اقتصادى در برابر سلامت و ارتقاء آن بررسىشده

است. [YY

در مطالعهاى ديخر، ابعاد مسئوليت اجتماعى به ينج بعد رهبرى و فرآيندهاى درونى، بازار (مشتريان)، محيط كار (كار كنان)، محيطزيست و جامعه و كشور تقسيمشده است [r] كه مدل اخير به دليل فراگيرتر بودن در يثوهش حاضر استفاده شد. شناخت وضعيت موجود ازنظر سطح مسئوليت اجتماعى بيمارستانها مىتواند به برنامه ريزان و مديريت

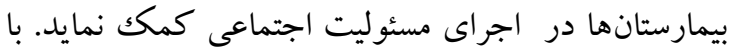
اجراى برنامه تحول سلامت تغييرات قابلتوجهى در نظام سلامت و مسئوليتهاى اجتماعى مرتبط ايجاد شد كه منجر به انجام بيزوهش حاضر جهت شناخت وضعيت موجود كرديد. با توجه به اهميت موضوع و نقش آن در بهبود و ارتقا ارائه خدمات سلامت، بثزوهش حاضر باهدف بررسى مسئوليت اجتماعى و ابعاد آن در بيمارستانهاى دانشخاهى دولتى شهر مشهد در سال Vوسا انجام گرفته است.

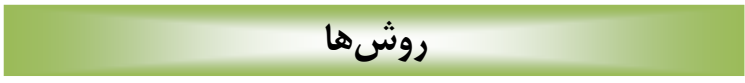

در اين مطالعه تحليلى-مقطعى و كاربردى، مسئوليت اجتماعى در سا بيمارستان دولتى دانشكاه علوم بزشكى مشهد، با نظرخو اهى درمجموع سلr نفر از مديران، كار كنان و مشتريان بررسى شد (هفت يرسشنامه نامعتبر تكميل شده شناسايى و از روند بثوهش حذف شدهاند). جهت گردآورى 
T- Tعيار) و تحليل آزمون مقايسه ميانگين يك نمونه (S) Student
بيماران در هر بيمارستان بررسى شدند. دادهها بهصورت

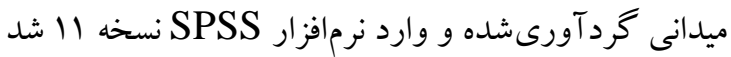
و با استفاده از آمار توصيفى (فراوانى، ميانگين و انحراف
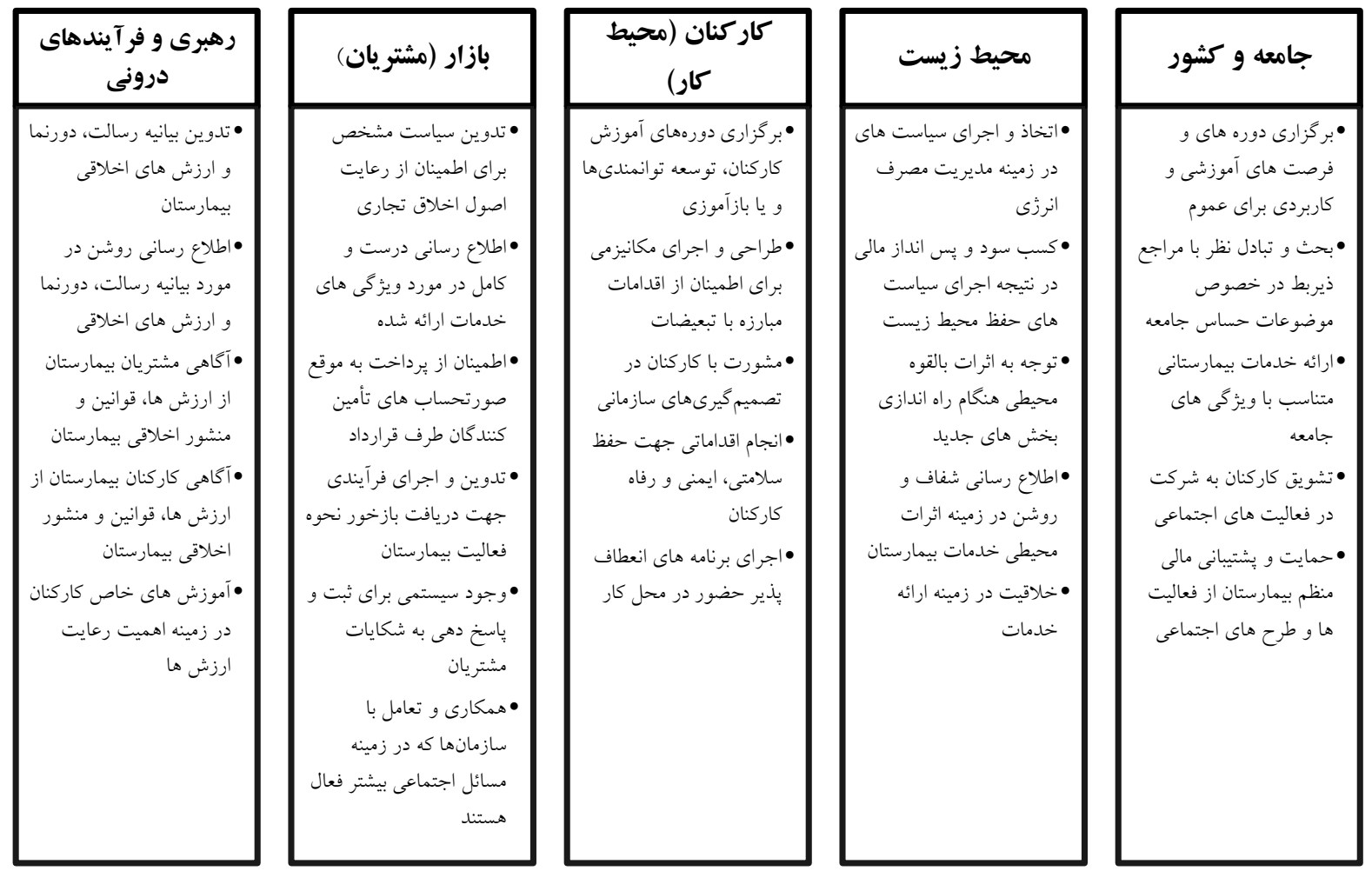

شكل ا- مدل مربوط به ابعاد و مؤلفهاى مسئوليت اجتماعى در سازمان

سطح متوسط يعنى دو دارد (T/1) و با توجه به مثبت بودن

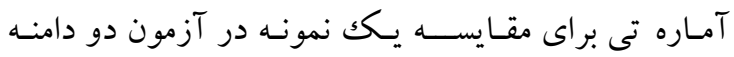

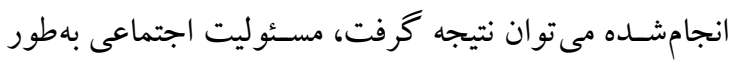

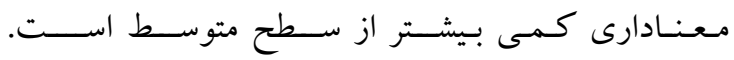
(Pvalue $\leq \cdot / \cdot \Delta)$

بر اسـاس مقادير احتمال براى ابعاد رهبرى و فر آيندهاى درونى

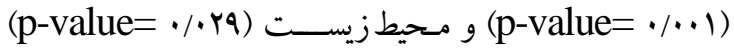
بهور معنى دار ميانگين بيشتر از متوسط بوده اسـت. ابعاد محيط

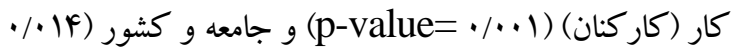

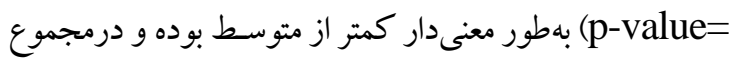

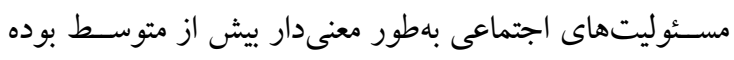

است (r.../p-value

\section{يافته ها}

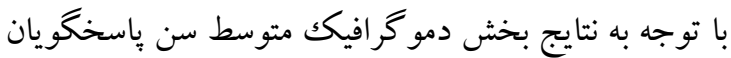

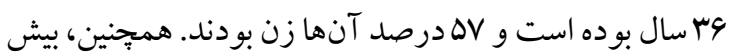
از نيمى (ه9./) از آنها داراى تحصيلات دانشگاهى بودهاند. جدول شماره يك، ميانخين امتياز ابعاد مسئوليت اجتماعى در هر بيمارستان بر اساس برسشنامهها را نشان مىدهد.

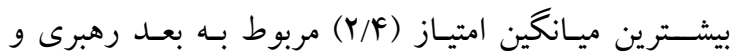

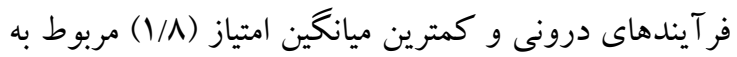
بعد محيط كار بود. سـاير ميانخين امتيازها به ترتيب بيشترين

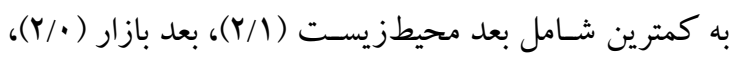

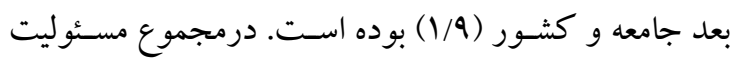

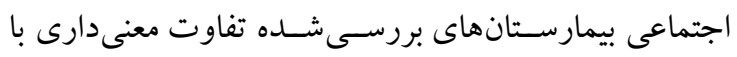


وضعيت مسئوليت اجتماعى و ابعاد...

جدول 1: ميانكين (انحر اف معيار) امتياز ابعاد مسئوليت اجتماعى در بيمارستانهاى بر رسى شيده ازنظر مشار كت كنند كان (مديران، كار كنان و مشتريان)

\begin{tabular}{|c|c|c|c|c|c|c|}
\hline 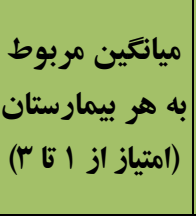 & جامعه و كشور & (امتياز از ا تا r) & $\begin{array}{c}\text { (كار كنان) } \\
\text { (امتياز از اتا rار) }\end{array}$ & بازار (مشتريان) & 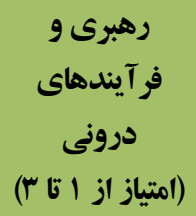 & ن ام بيمارستان \\
\hline $1 / 9\left(\cdot / \sim^{\prime}\right)$ & $r / F(\cdot / V \Lambda)$ & $1 / f(\cdot / V q)$ & $1 / 9(\cdot / F r)$ & $r / \cdot(\cdot / r \Delta)$ & $r / r(\cdot / 9 V)$ & بيمارستان \\
\hline$Y / \Lambda(\cdot / F Y)$ & $r / 9(\cdot / A Y)$ & $r / F(\cdot / \wedge q)$ & $1 / 9(\cdot / F F)$ & $1 / \Lambda(\cdot / Y \Lambda)$ & $r / Y(\cdot / \Delta r)$ & بيمارستان r \\
\hline $1 / \Lambda(\cdot / r Y)$ & $1 / 9(\cdot / 9 Y)$ & $1 / 4(\cdot / 9 \mathrm{~V})$ & $1 / A(\cdot / \mathcal{A V})$ & $r / \cdot(\cdot / r q)$ & $r / \Lambda(\cdot / F V)$ & بيمارستان r \\
\hline $1 / 9(\cdot / 41)$ & $1 / 4(\cdot / \Delta \Lambda)$ & $1 / \wedge(\cdot / V \Lambda)$ & $r / \cdot(\cdot / \Delta \cdot)$ & $r / l(\cdot / F q)$ & $r / F(\cdot / 99)$ & بيمارستان ع \\
\hline$l / \Lambda(\cdot / r V)$ & $I / F(\cdot / \Delta V)$ & $1 / \Lambda(\cdot / N \mu)$ & $1 / 9(\cdot / 4 \cdot)$ & $r / \cdot(\cdot / \mu l)$ & $r / F(\cdot / 9 \cdot)$ & بيمارستان ه \\
\hline $1 / 9(\cdot / \mu 4)$ & $1 / 9(\cdot / 9 r)$ & $1 / f(\cdot / q V)$ & $1 / 9(\cdot / F r)$ & $r / I(\cdot / \kappa \Delta)$ & $r / \Delta(\cdot / 99)$ & بيمارستان 7 \\
\hline$r / r(\cdot / \Delta r)$ & $1 / 1(\cdot / 9 \Lambda)$ & $r / \Lambda(\cdot / A V)$ & $r / I(\cdot / \Delta \Delta)$ & $r / \cdot(\cdot / r \Delta)$ & $r / 9(\cdot / 9 \mathrm{~V})$ & Vيمارستان V V \\
\hline$r / M(\cdot / F r)$ & $r / \cdot(\cdot / V I)$ & $Y / Y(\cdot / V q)$ & $1 / V(\cdot / 44)$ & $r / l(\cdot / V q)$ & $r / 9(\cdot / 94)$ & ي يمارستان \\
\hline$r / N(\cdot / F r)$ & $1 / 9(\cdot / 94)$ & $r / \Lambda(\cdot / q \cdot)$ & $1 / V(\cdot / 44)$ & $r / \cdot(\cdot / r I)$ & $r / F(\cdot / 91)$ & بيمارستان 9 \\
\hline$r / Y(\cdot / \Delta 1)$ & $r / F(\cdot / V \Lambda)$ & $r / 9(\cdot / V q)$ & $1 / \Lambda(\cdot / F V)$ & $1 / \Lambda(\cdot / T V)$ & $r / F(\cdot / 90)$ & بيمارستان • \\
\hline$r / 9\left(\cdot / T^{\prime}\right)$ & $r / \cdot(\cdot / 9 Y)$ & $r / \cdot(\cdot / 9 r)$ & $r / 9(\cdot / 09)$ & $r / r(\cdot / \& q)$ & $r / \Gamma(\cdot / 9 \cdot)$ & بيمارستان 11 \\
\hline $1 / \Lambda(\cdot / \mu F)$ & $1 / F(\cdot / \Delta F)$ & $1 / \Lambda(\cdot / \vee q)$ & $1 / q(\cdot / F V)$ & $1 / \Delta(\cdot / \cdot Y)$ & $r / \Delta(\cdot / 9 \Lambda)$ & بيمارستان r| \\
\hline$r / \cdot(\cdot / r q)$ & $1 / \Lambda(\cdot / 9 \Lambda)$ & $1 / 9(\cdot / V \Delta)$ & $1 / 9(\cdot / 01)$ & $r / Y(\cdot / f q)$ & $r / \Delta(\cdot / 94)$ & بيمارستان سا \\
\hline$Y / I(\cdot / Y F)$ & $1 / 9(\cdot / 0 \cdot)$ & $Y / T(\cdot / \Delta 9)$ & 1/N(•/T) & $r / \cdot(\cdot / r \Delta)$ & $r / F(\cdot / r I)$ & 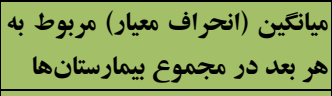 \\
\hline$\cdot / \cdot r$ &.$/ \cdot 1 f$ &.$/ \cdot r q$ &.$/ \cdot 1$ & $\cdot / 4 \cdot V$ &.$/ \cdot 1$ & مقدار احتمال (P-value) \\
\hline
\end{tabular}

(r) آزمون تى جهت مقايسه ميانخين با عدد متوسط (r)

تعيينشده (ارائه خدمات مستمر بهصورت شبانهروزى) نمى تواند به شكل مطلوبى منعطف باشد و جهت تكميل نوبتهاى كارى مشوقهايى تعريفشده است كه مىتوان با آكاهسازى كاركنان در دورههاى توجيهى بدو خدمت نارضايتى را تعديل نمود. از ديخر نتايج مؤلفه هاى مربوط به اين بعد، وجود تبعيض در سازمان بوده است كه به دليل اختلاف شديد برداختىها در دانشگاه رخداده است. جهت حل اين موضوع تدوين دستور العمل هاى مشخص برداخت مبتنى بر عملكرد (مشابه طرح قاصدكك) مى تواند مفيد واقع شود. در نظريه هاى مديريت دولتى نوين به لزوم توجه به نيروى انسانى باهدف كارايى و اثربخشى سازمانى نيز بسيار
جدول r: ميانغين ابعاد مسئوليت اجتماعى در گروه

$$
\text { بيماران، كار كنان و مديران }
$$

\begin{tabular}{|c|c|c|c|}
\hline انحراف & بانكين & تعداد & \\
\hline$\cdot / \mathrm{Va}$ & $1 / 9$ & ir. & بيماران \\
\hline . Ar & $r / \cdot$ & ir. & كار كنان \\
\hline - /AF & $r / l$ & ir & مدير ان \\
\hline & & & $\begin{array}{l}\text { One way ANOVA } \\
F=1 / r r \tau P=\cdot / r q r\end{array}$ \\
\hline
\end{tabular}

\section{بحث}

در بعد مسئوليت اجتماعى سازمان در محيط كار مهمترين مشكل انعطافيذير نبودن سازمان براى كاركنان در نوبتهاى كارى است كه سازمان با توجه به رسالت 
اين زمينه، از طريق افزايش آكاهى كاركنان، مىتواند مسئوليت اجتماعى سازمان در بعد رهبرى و فرآيندهاى درونى را ارتقاء دهد. در بعد مسئوليت اجتماعى سازمان در قبال محيطزيس، مهم ترين مسئله اعلامشده نگًاه مالى دانشگاه به مشكلات اين حوزه بوده است كه دانشكاه مىتواند با مديريت مصرف انرزى و استفاده از سوختهاى جايكزين علاوه بر كاهش هزينها تا حدودى به ارتقاء وضعيت محيطزيست كمكك نمايد. زراعتكار در مطالعه خود نشان داد وجود سطح دانش و آكاهى در سطوح شغلى شرط لازم براى بهبود مديريت بسماندهاى بيمارستانى و مصرف انرزى است. [YY] در مؤلفهاى مربوط به مسئوليت اجتماعى سازمان در قبال مشتريان (بازار) مهم ترين نتيجه بر گرفتهشه از يثروهش، عدم اطمينان مشتريان در مسائل مالى بوده است كه با توجه به مشكلات مالى موجود در سازمان اين موضوع كاملاً طبيعى به نظر مىرسد و يكى از بهترين روشها جهت كاهش نارضايتى، لحاظ مسائل مربوطه در زمان عقد قرارداد است. در قسمت نتايج مقايسه مسئوليت اجتماعى در بين بيمارستانها، امتيازها بسيار نزديكك به هم بود كه مىتوان با ايجاد فضاى رقابتى بين بيمارستانها در راستاى ارتقا مسئوليت اجتماعى كامهاى مؤثرى برداشت. درمجموع سطح مسئوليت اجتماعى بيمارستانها متوسط نزديكك به خوب ارزيابى شدو و

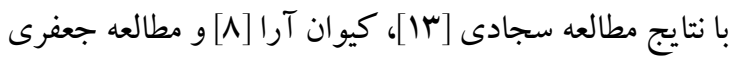
يويان [TV] مشابه بود و اين موضوع مى تواند حاكى از آكاهى

مسئولين و تغيير رويكرد سازمانها از توجه صرف به مسائل مادى به مسائل اجتماعى و زيستمحيطى و درنتيجه لزوم اجراى آن باشد. از محدوديتهاى يثروهش حاضر، احتمال ارائه نظرات برخى از مديران همراه با تعصب در ياسخدهى يرسشنامه در بعد رهبرى و فر آيندهاى درونى به دليل ترس
״رداختهشده است. [rr] در بحث مشاركت كاركنان در تصميم گيرىهاى سازمانى، ميزان مشاركت كاركنان در تصميم گيرىهاى استر اتزيكك را درحد بايين بيان نموده بودند كه با نتايج مطالعه زهاوى مشابهت داشته است. [YF] همجِنين، پايين بودن سطح مسئوليت اجتماعى در بعد كار كنان با نتايج مطالعه حائرى همراستا بود. [YهD] در بعد مسئوليتهاى اجتماعى سازمان در قبال جامعه و كشور بعد از محيط كار (كار كنان) بهعنوان بايينترين ميانگين در امتياز مسئوليت اجتماعى مطرح شد كه با توجه به امتياز مؤلفهاى يزوهش در اين خصوص مىتوان با تدوين سياستهايى براى مشاركت بخش غيردولتى و خيريهها و نيز اجراى برنامههاى آموزشى براى مديران بخش بهداشت و درمان كشور، ارتقا مسئوليت اجتماعى را در اين بعد بهبود بخشيد. برواضح است نقش جامعه و كشور بهعنوان يكى از ابعاد مسئوليت اجتماعى سازمان، تنها مشمول كمككها و در قالب تشكيل شوراى مشار كت مردمى نيست بلكه، ابعاد بسيار كستردهاى مى تواند داشته باشد و شر كتها و نهادها بهعنوان عضوى از جامعه و كشور، گامهاى مؤثرى را در راستاى مسئوليت اجتماعى مى تو انند داشته باشند. در بعد رهبرى و فر آيندهاى درونى، بعد محيطزيست و بعد بازار (مشتريان) به ترتيب بيشترين ميانخين امتياز مسئوليت اجتماعى را به خود اختصاص دادند. با توجه به نتايج حاصل مىتوان كفت كه رسالت، استراتزىها و اهداف سازمان براى كار كنان بهاندازه كافى روشن نبوده است و مىتوان با تبيين كامل رسالت و استراتزىها و اهداف سازمان در اين بعد مسئوليت اجتماعى سازمان را بهبود داد و حمايت مديران ارشد از استراتزىهاى تعيينشده براى سازمان مىتواند روشنبخش راه سازمان براى تمامى كار كنان باشد و در بايان با توجه به نتايج حاصل از برسشنامه، آموزش كار كنان در 
دانشگاه علوم يزشكى مشهد انجامشده است. جهت رعايت

ملاحظات اخلاقى شركت در اين بثزوهش اختيارى بوده است

و علاوه بر حفظ محرمانكى اطلاعات شركت كنند مان رضايت كتبى از پاسخگُويان اخذ گرديد.

حمايت مالى: اين يُزوهش با حمايت مالى دانشگاه علوم

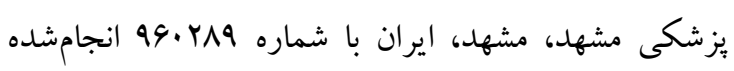

تضاد منافع: نويسندگان اظهار داشتند كه تضاد منافعى

$$
\text { وجود ندارد. }
$$

تشكر و قدردانى: اين مقاله حاصل بخشى از بايانامه با عنوان (بررسى مسئوليت اجتماعى بيمارستانهاى دانشكاه علوم يزشكى مشهد در طى سالهاى به تا وه و ارائه راه كارهاى ارتقاء آن)، مصوب دانشگاه علوم يزشكى مشهد، در سال 9 است. يُزوهشخر بر خود لازم مىداند از همكارى مدير ان محترم بيمارستانهاى دانشكاه علوم يزشكى مشهد و نيز تمامى افرادى كه در راستاى اجراى آن با يثزوهشخر همكارى نمودند، تشكر و قدردانى نمايد.
وضعيت مسئوليت اجتماعى و ابعاد... از دست رفتن وجهه بيمارستان بود. اطلاعات ئزوهش حاضر بر اساس اطلاعات بيمارستانهاى دانشخاه علوم يزشكى مشهد بوده است و قابل تعميم به ساير دانشگاهها و بخش خصوصى در راستاى افزايش مسئوليتهاى اجتماعى سازمان ابتدا لازم است رسالت، اهداف و همجنين، استراتزىها بهروشنى تبين كردند و ضمن حمايت مديران ارشد از اجراى استراتزىها جهت حصول اهداف، در راستاى افزايش آكاهى جامعه و كار كنان كام بردارد و با شناخت وظايف و اهداف انتظار مىرود با متوازنسازى توقعات در جامعه و كار كنان، احساس آنها از مسئوليتهاى اجتماعى سازمان تغيير يابد. علاوه بر آن، با توجه به اوضاع اقتصادى موجود نياز است در كنار مديريت بهينه منابع انسانى، فيزيكى و مالى با شفافسازى وضعيت در راستاى همراهى كار كنان و مشتريان گام بردارد.

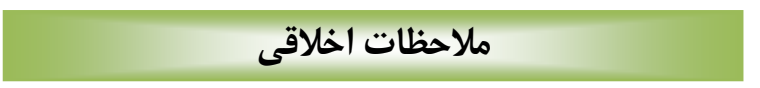
رعايت دستورالعملهاى اخلاقى: اين يزوهش با كد اخلاق به شماره 99199 اخذشده از كميته اخلاق و ئزوهش

\section{References}

1. Vélaz I, Sison A, Fontrodona J. Incorporating CSR and stakeholder management into corporate strategy: the CAN experience 2002-2006. Emerald Insight. 2006;7(4):434-45.

2. Dahlsrud A. How corporate social responsibility is defined: an analysis of $\mathbf{3 7}$ definitions. Corporate social responsibility and environmental management. 2008;15(1):1-13.

3. Mousazadeh Y, Gholizadeh M, Janati A, Amirshakeri F, Narimani M. The Perspectives of Head Nurses and Managers of Private and Public Hospitals of Tabriz City about Social Responsibility. Journal of Health Based Research. 2017;3(3):203-16.[In Persian]

4. Govindan K, Kannan D, Shankar KM. Evaluating the drivers of corporate social responsibility in the mining industry with multi-criteria approach: A multi-stakeholder perspective. Journal of cleaner production. 2014;84(1):214-32. 
ابراهيمى يور و همكاران

5. Liu W, Shi L, Pong RW, Chen Y. How patients think about social responsibility of public hospitals in China? BMC Health Services Research. 2016;16(1):371.

6. Camilleri MA. Corporate sustainability and responsibility: creating value for business, society and the environment. Asian Journal of Sustainability and Social Responsibility. 2017;2(1):59.

7. Christopher J. Corporate governance-A multi-theoretical approach to recognizing the wider influencing forces impacting on organizations. Critical perspectives on accounting. 2010;21(8):683-95.

8. Keyvanara M, Sajadi HS. Social responsibility of the hospitals in Isfahan city, Iran: Results from a cross-sectional survey. International journal of health policy and management. 2015;4(8):517.[In Persian]

9. Ajdary A, Nayebzadeh S, Heirany F. The effect of social responsibility on hospital brand value case study: Shahid Sadoughi Hospital of Yazd. Journal of Health Administration (JHA). 2015;18(61):45-31.[In Persian]

10. Shi G, O'Rourke M, Liu J, Zhong D, Liu X, Li J. Organisational reform in healthcare in China: impacts on the social functions of public hospitals. Australian Health Review. 2003;26(3):61-72.

11. Ahmadi K, Alvani SM, Memarzade TG. Concept of Corporate Social Responsivenes And Necessity of Designing a Mechanism for Measurement in the Public Sector of Iran. Journal of Development \& Evolution Management 2013;5(14):1-7.[In Persian]

12. Maignan I, Ferrell O. Nature of corporate responsibilities: Perspectives from American, French, and German consumers. Journal of Business research. 2003;56(1):55-67.

13. Sajadi HS, Asadi H, Mohaghegh B. The relationship between management style and social responsibility at Tehran hospitals. Medical Journal of Hormozgan University. 2015;18(5):45564.[In Persian]

14. Ghorbani M, Zarandi M, Hesari R. Ethics and social responsibility managers. Tomorrow management. 2005;3(11,12):79-92.[In Persian]

15. Hejazi r, Nasiri s. Corporate Citizen Concepts and Social Responsibility. Accounting Research. 2015;4(3):163-83.[In Persian]

16. Brandao C, Rego G, Duarte I, Nunes R. Social responsibility: a new paradigm of hospital governance? Health Care Analysis. 2013;21(4):390-402.

17. Clarkson ME. A stakeholder framework for analyzing and evaluating corporate social performance. Academy of management review. 1995;20(1):92-117.

18. Aryankhesal A, Etemadi M, Agharahimi Z, Rostami E, Mohseni M, Musavi Z. Analysis of social functions in Iran's public hospitals: pattern of offering discounts to poor patients. International Journal of Human Rights in Healthcare. 2016;9(4):242-53.[In Persian] 
19. Zaboli R, Sanaeinasab H. The Challenges and Solutions for Action of Social Determinants of Health in Iran: A Qualitative Study. Iranian Journal of Health Education and Health Promotion. 2014;2(1):5-16.[In Persian]

20. Arabsalehi M, Sadeghi G, Moeinodein M. The relationship of social responsibility with the financial performance of companies admitted to the Tehran Stock Exchange. Empirical Accounting Research. 2013;3(1):1-20.[In Persian]

21. Ghasemi F. Corporate Social Responsibility and How It Measure. Monthly Journal of Applied Studies in Management and Development Sciences. 2016;1(2):43-54.[In Persian]

22. Khosravi $\mathrm{Y}$, Keshavarzmohammadi N, Farshad A, at al. Organizational social responsibility accuntability for health(A tool for OSRAH).Global Health Promotion. 2016:10.[In Persian]

23. Attarian F, Mirsepassi N, MousaKhani M. Pathology of reform Civil Service Management Law the approach employees empowerment of state executive agencies. Iranian Journal of Public Administration Mission. 2016;7(2):1-16. [In Persian]

24. Zahavi M, Sadrmomtaz N, Arpanahei S. The rate of nursing staff participation in strategic decision making in Shariati Hospital. Journal of Paramedicine Faculty of Tehran University of Medical Sciences (Health Promotion). 2010;3(4):46-38. [In Persian]

25. Haery SM, Tehrani H, Olyaeimanesh A, Nedjat S. Factors influencing the social health of employees of the ministry of health and medical education in Iran. Iranian Journal of Health Education and Health Promotion. 2016;3(4):311-8.[In Persian]

26. Zeraatkar E, Rahmani H, Ghazi Asgar M, Saeid Pour J, Azami S, Aryankhesal A, et al. Waste Management in Selected Hospitals of Teheran University of Medical Sciences: Staff Awareness and Hospital Performance -2012. jhosp. 2014;12(4):91-8.[In Persian]

27. Jaafaripooyan E, Pourreza A, Rahimi Foroshani A, Maleki R. Assessing the Importance of Social Responsibility and Its Implementation Status in Kermanshah Teaching Hospitals from the Perspective of Management Team. jhosp. 2018;17(1):9-16.[In Persian] 